\title{
Discovery of Novel 3,3-Disubstituted Piperidines as Orally Bioavailable, Potent and Efficacious HDM2-p53 Inhibitors
}

\section{Supporting Information}

Stéphane L. Bogen*, ${ }^{a}$ Weidong Pan, ${ }^{a}$ Craig R. Gibeau, ${ }^{b}$ Brian R. Lahue, ${ }^{b}$ Yao Ma, ${ }^{b}$ Latha G. Nair, ${ }^{a}$ Elise Seigel, ${ }^{a}$ Gerald W. Shipps Jr., ${ }^{b}$ Yan, Tian, ${ }^{b}$ Yaolin Wang, ${ }^{c}$ Yinghui Lin, ${ }^{c}$ Ming Liu, ${ }^{c}$ Suxing Liu, ${ }^{c}$ Asra Mirza, ${ }^{c}$ Xiaoying Wang, ${ }^{c}$ Philip Lipari, ${ }^{c}$ Cynthia Seidel-Dugan, ${ }^{c}$ Daniel J. Hicklin, ${ }^{c}$ W. Robert Bishop, ${ }^{c}$ Diane Rindgen, ${ }^{d}$ Amin Nomeir, ${ }^{d}$ Winifred Prosise, ${ }^{e}$ Paul Reichert, ${ }^{e}$ Giovanna Scapin, ${ }^{e}$ Corey Strickland, ${ }^{e}$ and Ronald J. Doll ${ }^{a}$

${ }^{a}$ Discovery Chemistry, Kenilworth, NJ 07033

${ }^{\mathrm{b}}$ Discovery Chemistry, Boston, MA 02115

${ }^{c}$ Discovery Biology, Kenilworth, NJ 07033

${ }^{d}$ Pharmacokinetic, Pharmacodynamics and Drug Metabolism, Kenilworth, NJ 07033

${ }^{\mathrm{e}}$ Structural Chemistry, Kenilworth, NJ 07033

Merck Research Laboratories, United States

stephane.bogen@merck.com

General

All compounds tested were of a minimum of $90 \%$ purity as determined by LC-MS and NMR analysis. Normal phase column chromatography was carried out in the indicated solvent system (in the percentage of volume) using pre-packed silica gel cartridges for use on the Isco CombiFlash ${ }^{\circledR}$ or Biotage SP1®. Analytical thin layer chromatography (TLC) visualization was performed using $254 \mathrm{~nm}$ wavelength ultraviolet light. The LCMS analyses were performed using a Phenomenex Gemini C18, 5 micron, 50mm x 4.6 $\mathrm{mm}$ ID eluting at $1 \mathrm{~mL} / \mathrm{min}$ with a solvent gradient of 10 to $95 \% \mathrm{~B}$ over $5 \mathrm{~min}$, followed by $0.5 \mathrm{~min}$ at $95 \% \mathrm{~B}$ : solvent $\mathrm{A}=0.06 \% \mathrm{TFA}$ in water; solvent $\mathrm{B}=0.05 \% \mathrm{TFA}$ in acetonitrile. Nuclear Magnetic Resonance spectra were recorded on Varian spectrometers. Spectra were taken in the indicated solvent at ambient temperature, and the chemical shifts are reported in parts per million $(\operatorname{ppm}(\delta))$ relative to the lock of the 
solvent used. Resonance patterns are recorded with the following notations: br (broad), s (singlet), d (doublet), $\mathrm{t}$ (triplet), q (quartet), and $\mathrm{m}$ (multiplet). High resolution mass spectra (HRMS) were acquired by use of a Bruker Daltonics 7T Fourier transform ion cyclotron resonance (FTICR) mass spectrometer. Samples were dissolved in acetonitrile:water:acetic acid (50:50:0.1\%v/v), and ionized by use of electrospray ionization (ESI) yielding $[\mathrm{M}+\mathrm{H}]+$. External calibration was accomplished with oligomers of polypropylene glycol (PPG, average molecular weight $1000 \mathrm{Da}$.

IC50 values were determined as described in Zhang et. al. (Analytical Biochemistry, 2004, 331, 138-146). Cell viability assay was done using the Celltiter-Glo luminescent assay kit from Promega and the assay was performed according the manufacture's instruction.

tert-butyl 2-allyl-3-oxopiperidine-1-carboxylate (26a) and methyl 2-allyl-3oxopiperidine-1-carboxylate (26b)
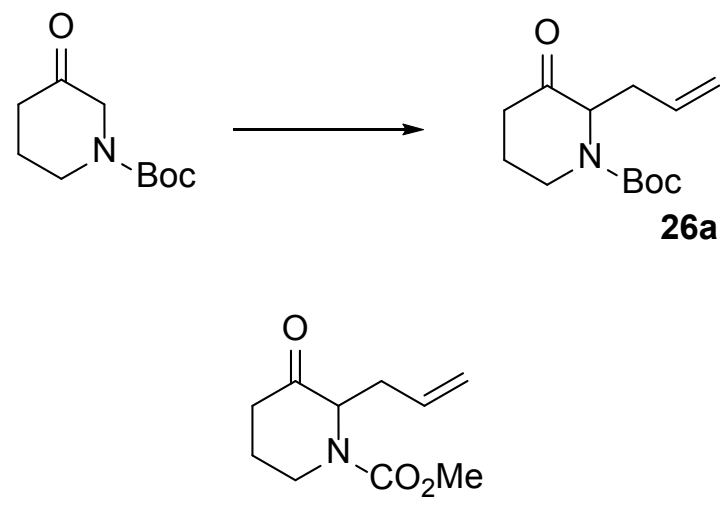

26b

Synthesis of 26b was describe in ref. 8(a) ACS Med. Chem. Lett. 2014, 5, 572-575. An identical procedure was used to prepare 26a starting from commercially available tert-butyl 3-oxopiperidine-1-carboxylate. 
(4-(2-(2-hydroxyethoxy)phenyl)piperazin-1-yl)((2R,3S)-2-propyl-1-(4-

(trifluoromethyl)nicotinoyl)-3-((4-(trifluoromethyl)thiophen-2-yl)oxy)piperidin-3-

yl)methanone (6) - general method 2<smiles>CCCC1N(C(=O)c2cnccc2C(F)(F)F)CCC[C@@]1(Oc1cc(C(F)(F)F)cs1)C(=O)N1CCN(c2ccccc2OCCO)CC1</smiles><smiles>C=CCC1N(C(C)=O)CCC[C@]1(Oc1cc(Br)cs1)C(=O)N1CCN(c2ccccc2OCCO[18O])CC1C(=O)O[C@]1(C(=O)O)CCCN(C(C)=O)[C@@H]1CC=C</smiles><smiles>C=CCC1NCCC[C@]1(Oc1cc(C(F)(F)F)cs1)C(=O)N1CCN(c2ccccc2OCCOC(C)=O)CC1</smiles><smiles></smiles>

Step 1 
A solution of 2,4-dibromothiophene $(3 \mathrm{~g}, 12.4 \mathrm{mmol})$ in $\mathrm{Et}_{2} \mathrm{O}(150 \mathrm{~mL})$ was cooled down to $-78^{\circ} \mathrm{C}$. $\mathrm{nBuLi}(7.8 \mathrm{~mL}, 12.4 \mathrm{mmol}$, 1eq.) was added. After 2 hours of stirring at this temperature, bis(trimethylsilyl)peroxide (2.22 g, $12.4 \mathrm{mmol}$, 1eq.) was added slowly and stirring was maintained while temperature was raised to room temperature. After 48 hours, the reaction mixture was diluted with hexane and filtrated through a pad of celite. The filtrate was concentrated in vacuo to approximately $20 \mathrm{~mL}$ then treated with $10 \mathrm{~mL}$ of a $2 \mathrm{M} \mathrm{HCl}$ in $\mathrm{Et}_{2} \mathrm{O}$. The reaction mixture was stirred for 1 hour. The solvent was removed in vacuo and the crude residue purified by flash silica gel chromatography $(8: 2$ hexane/EtOAc) to give $1.2 \mathrm{~g}$ (54\% yield) of 4-bromothiophen-2-ol. ${ }^{1} \mathrm{H}$ NMR (400 MHz, $\left.\mathrm{CDCl}_{3}\right) \delta 6.54(\mathrm{~s}, 1 \mathrm{H}), 4.27(\mathrm{~m}, 1 \mathrm{H})$.

At room temperature, to 4-bromothiophen-2-ol (170 mg, $0.95 \mathrm{mmol}, 1$ eq.) in THF (2 mL) was added dry $\mathrm{NaOH}$ (228 mg, $5.7 \mathrm{mmol}$, 6eq.). Stirring was maintained for $0.5 \mathrm{~h}$ then a solution of $\mathbf{2 6 b}$ (1.25 eq, $1.2 \mathrm{mmol}, 240 \mathrm{mg}$ ) in extra dry THF (2 mL) was added. Stirring was with stirring for $20 \mathrm{~min}$ at room temperature. The reaction mixture was then cooled to $0{ }^{\circ} \mathrm{C}$, and extra dry chloroform $(0.38 \mathrm{~mL}, 4.8 \mathrm{mmol}$, 5eq. $)$ was added dropwise. The reaction mixture was then warmed to room temperature for $2 \mathrm{~h}$, and then heated to $45^{\circ} \mathrm{C}$ overnight. The reaction mixture was cooled to room temperature and diluted with EtOAc $(50 \mathrm{~mL})$. The $\mathrm{pH}$ was adjusted to $\mathrm{pH} 4$ with $1.0 \mathrm{~N} \mathrm{HCl}$ and the aqueous layer was separated. The aqueous solution was extracted with ethyl acetate $(3 \times 25 \mathrm{~mL})$. The combined extracts were dried over $\mathrm{MgSO}_{4}$, filtered and evaporated to dryness. The residue was purified by reverse phase HPLC (10->95\% $\mathrm{CH}_{3} \mathrm{CN}$ in water with $0.1 \%$ TFA) to provide 2-allyl-3-((4-bromothiophen-2-yl)oxy)-1-(methoxycarbonyl)piperidine-3carboxylic acid $\mathbf{2 7 b}$ (170 mg, 44\% yield) as a racemic mixture used directly in step 2. LCMS m/z $=404.2(\mathrm{M}+\mathrm{H})+$.

Step 2:

To a room temperature solution of 2-allyl-1-(methoxycarbonyl)-3-((4(trifluoromethyl)thiophen-2-yl)oxy)piperidine-3-carboxylic acid 27b ( $170 \mathrm{mg}, 0.42$ $\mathrm{mmol}$ ) in DCM/DMF (10 mL, 5:1) was added 2-(2-(piperazin-1-yl)phenoxy)ethyl acetate hydrochloride (126 mg, $0.42 \mathrm{mmol}, 1$ eq.), HATU (191 mg, $0.5 \mathrm{mmol}, 1.2$ eq.) and DIPEA (0.42 mL, $2.52 \mathrm{mmol}$, 6eq.). The reaction was heated to $40^{\circ} \mathrm{C}$ overnight. The reaction was cooled to room temperature, and then was diluted with a saturated aqueous 
solution of $\mathrm{NH}_{4} \mathrm{Cl}$ water and extracted with EtOAc. The combined organic layers were washed with brine and dried over MgSO4. The extracts were concentrated and chromatographed over a column of $\mathrm{SiO} 2$ (5->80\% EtOAc / hexanes as eluent) to provide $170.5 \mathrm{mg}$ (62\% yield) of methyl-3-(4-(2-(2-acetoxyethoxy)phenyl)piperazine-1carbonyl)-2-allyl-3-((4-bromothiophen-2-yl)oxy)piperidine-1-carboxylate 6a. LCMS m/z $=651.3(\mathrm{M}+\mathrm{H})+.{ }^{1} \mathrm{H}$ NMR $\left(400 \mathrm{MHz}, \mathrm{CDCl}_{3}\right) \delta$ 7.06-6.92 (m, 2H), 6.91-6.84 (m, 2H), $6.58(\mathrm{dd}, J=2 \mathrm{~Hz}, 1 \mathrm{H}), 6.22(\mathrm{dd}, J=2 \mathrm{~Hz}, 1 \mathrm{H}), 5.79-5.57(\mathrm{~m}, 1 \mathrm{H}), 5.15-4.94(\mathrm{~m}, 4 \mathrm{H})$, 4.50-4.42 (m, 2H), 4.26-4.15 (m, 3H), 4.03-3.92 (m, 2H), $3.74(\mathrm{~s}, 2 \mathrm{H}), 3.72-3.62(\mathrm{~m}$, 2H), 3.24-3.13 (m, 1H), 3.11-2.97 (m, 2H), 2.93-2.78 (m, 2H), 2.59-2.45 (m, 2H), 2.24$2.15(\mathrm{~m}, 1 \mathrm{H}), 2.09(\mathrm{~s}, 3 \mathrm{H}), 1.74-1.56(\mathrm{~m}, 2 \mathrm{H}), 1.52-1.39(\mathrm{~m}, 1 \mathrm{H})$.

Step 3:

To a room temperature solution of methyl-3-(4-(2-(2-acetoxyethoxy)phenyl)piperazine-1carbonyl)-2-allyl-3-((4-bromothiophen-2-yl)oxy)piperidine-1-carboxylate (75 mg, 0.12 mmol) in anhydrous DMF/HMPA (5 mL, 2:1) was added CuI (18 mg, $0.096 \mathrm{mmol}$, 0.8eq.). The mixture was stirred and heated to $75^{\circ} \mathrm{C}$, then methyl 2,2-difluoro-2(fluorosulfonyl)acetate (38 uL, $0.3 \mathrm{mmol}, 2.5$ eq.) in $1 \mathrm{~mL}$ of DMF was added dropwise over a period of $2 \mathrm{hr}$. The mixture was stirred at $75^{\circ} \mathrm{C}$ overnight. The reaction was cooled to room temperature, and then was diluted with water and extracted with EtOAc. The combined organic layers were washed with brine and dried over MgSO4. The extracts were concentrated and chromatographed over a column of $\mathrm{SiO} 2$ (5->80\% EtOAc / hexanes as eluent) to provide $53 \mathrm{mg}$ (72\% yield) of methyl-3-(4-(2-(2acetoxyethoxy)phenyl)piperazine-1-carbonyl)-2-allyl-3-((4-(trifluoromethyl)thiophen-2yl)oxy)piperidine-1-carboxylate 6b. LCMS m/z = $640.5(\mathrm{M}+\mathrm{H})+$.

Step 4:

To a $0^{\circ} \mathrm{C}$ solution of methyl-3-(4-(2-(2-acetoxyethoxy)phenyl)piperazine-1-carbonyl)-2allyl-3-((4-(trifluoromethyl)thiophen-2-yl)oxy)piperidine-1-carboxylate (53 $\mathrm{mg}, 0.083$ mmol) in anhydrous $\mathrm{CH}_{2} \mathrm{Cl}_{2}(10 \mathrm{~mL})$ was added TMS-I $(68 \mathrm{uL}, 0.50 \mathrm{mmol}$, 6eq.) in $\mathrm{CH}_{2} \mathrm{Cl}_{2}(2 \mathrm{~mL})$. The mixture was stirred at room temperature overnight then diluted with EtOAc $(25 \mathrm{~mL})$ washed with sat. $\mathrm{NaHCO}_{3}$. The combined organic layers were washed with brine and dried over MgSO4. The extracts were concentrated and purified by reverse phase $\mathrm{HPLC}\left(5->95 \% \mathrm{CH}_{3} \mathrm{CN}\right.$ in water with $0.1 \%$ TFA) to provide $10 \mathrm{mg}$ of 2- 
(2-(4-(2-allyl-3-((4-(trifluoromethyl)thiophen-2-yl)oxy)piperidine-3-carbonyl)piperazin1-yl)phenoxy)ethyl acetate 33 that was used directly in step5. LCMS $\mathrm{m} / \mathrm{z}=582.6$ $(\mathrm{M}+\mathrm{H})+$.

Step 5:

To 2-(2-(4-(2-allyl-3-((4-(trifluoromethyl)thiophen-2-yl)oxy)piperidine-3-carbonyl)piperazin-1-yl)phenoxy)ethyl acetate 33 ( $10 \mathrm{mg}, 0.017 \mathrm{mmol}$ ) in DCM was added HATU ( $8 \mathrm{mg}, 0.02 \mathrm{mmol}, 1.2 \mathrm{eq})$, DIPEA ( $28 \mathrm{uL}, 0.17 \mathrm{mmol}, 10 \mathrm{eq}$.$) at 0^{\circ} \mathrm{C}$, then $4-$ (trifluoromethyl)nicotinoyl chloride $(7.1 \mathrm{mg}, 0.034 \mathrm{mmol}, 2 \mathrm{eq}$.$) . The reaction was stirred$ at room temperature for 2 hours, and then was diluted with a saturated aqueous solution of $\mathrm{NH}_{4} \mathrm{Cl}$ water and extracted with EtOAc. The combined organic layers were washed with brine and dried over $\mathrm{MgSO} 4$. The extracts were concentrated and purified by reverse phase HPLC (10->95\% $\mathrm{CH}_{3} \mathrm{CN}$ in water with $0.1 \% \mathrm{TFA}$ ) to provide $10.1 \mathrm{mg}$ (79\% yield) of 2-(2-(4-(2-allyl-1-(4-(trifluoromethyl)nicotinoyl)-3-((4-(trifluoromethyl)thiophen-2yl)oxy)piperidine-3-carbonyl)piperazin-1-yl)phenoxy)ethyl acetate 34 that was used directly in step 6. LCMS m/z $=755.6(\mathrm{M}+\mathrm{H})+$.

Step 6:

To 2-(2-(4-(2-allyl-1-(4-(trifluoromethyl)nicotinoyl)-3-((4-(trifluoromethyl)thiophen-2yl)oxy)piperidine-3-carbonyl)piperazin-1-yl)phenoxy)ethyl acetate $\mathbf{3 4}(10.1 \mathrm{mg}$, $0.013 \mathrm{mmol})$ in $\mathrm{MeOH}(2 \mathrm{~mL})$ was added $10 \% \mathrm{Pd} / \mathrm{C}(2 \mathrm{mg}, 20 \% \mathrm{w} / \mathrm{w}))$ and the reaction mixture purged with $\mathrm{H}_{2}$. After stirring at room temperature $2 \mathrm{~h}$, the mixture was filtered through celite and concentrated in vacuo to give $4.2 \mathrm{mg}$ (40\% yield) of 2-(2-(4-(2propyl-1-(4-(trifluoromethyl)nicotinoyl)-3-((4-(trifluoromethyl)thiophen-2-

yl)oxy)piperidine-3-carbonyl)piperazin-1-yl)phenoxy)ethyl acetate. $\mathrm{MeOH}(2 \mathrm{~mL})$ and $1.0 \mathrm{M} \mathrm{LiOH}(0.017 \mathrm{~mL}, 0.017 \mathrm{mmol}, 3$ eq. $)$ were added. The reaction mixture was stirred at room temperature overnight then concentrated in vacuo. The crude mixture was purified by reverse phase HPLC (10->95\% $\mathrm{CH}_{3} \mathrm{CN}$ in water with $0.1 \%$ TFA) to provide to give $2.8 \mathrm{mg}$ (70\% yield) of (4-(2-(2-hydroxyethoxy)phenyl)piperazin-1-yl)(2-propyl-1(4-(trifluoromethyl)nicotinoyl)-3-((4-(trifluoromethyl)thiophen-2-yl)oxy)piperidin-3yl)methanone 6 as a racemic mixture. LCMS $\mathrm{m} / \mathrm{z}=715.40(\mathrm{M}+\mathrm{H})+.{ }^{1} \mathrm{H}$ NMR $(400 \mathrm{MHz}$, $\mathrm{CDCl}_{3}$ - mixture of rotamers), $\delta 8.86(\mathrm{~s}, 1 \mathrm{H}), 7.66(\mathrm{~s}, 1 \mathrm{H}), 7.13-6.98(\mathrm{~m}, 3 \mathrm{H}), 6.91-6.86$ (m, 2H), $6.40(\mathrm{~d}, J=12 \mathrm{~Hz}, 1 \mathrm{H}), 5.53(\mathrm{~d}, J=12 \mathrm{~Hz}, 1 \mathrm{H}), 4.28-4.10(\mathrm{~m}, 3 \mathrm{H}), 3.83-3.62$ 
(m, 3H), 3.28-2.98 (m, 4H), 2.53-2.33 (m, 2H), 1.96-1.84 (m, 1H), 1.67-1.37 (m, 8H), $1.31-1.20(\mathrm{~m}, 3 \mathrm{H}), 1.08-0.97(\mathrm{~m}, 3 \mathrm{H})$.

Preparation of key intermediates 5a for synthesis of target 5 (Table 1)<smiles>C=CC[C@H]1N(C(C)=O)CCC[C@@]1(Oc1cc(Br)cs1)C(=O)N1CCN(c2ccccc2OCCOC(C)=O)CC1</smiles><smiles>C=CC[C@H]1NCCC[C@]1(Oc1cc(I)cs1)C(=O)N1CCN(c2ccccc2OCCOC(C)=O)CC1</smiles>

To a $0^{\circ} \mathrm{C}$ solution of methyl-3-(4-(2-(2-acetoxyethoxy)phenyl)piperazine-1-carbonyl)-2allyl-3-((4-bromothiophen-2-yl)oxy)piperidine-1-carboxylate $6 \mathbf{a}(45 \mathrm{mg}, 0.070 \mathrm{mmol})$ in anhydrous $\mathrm{CH}_{2} \mathrm{Cl}_{2}(10 \mathrm{~mL})$ was added TMS-I (60 uL, $0.42 \mathrm{mmol}, 6$ eq.). The mixture was stirred at room temperature for $20 \mathrm{hrs}$. The reaction was diluted with sat. $\mathrm{NaHCO}_{3}$ and extracted with EtOAc. The combined organic layers were washed with brine and dried over MgSO4. The extracts were concentrated and Dried over $\mathrm{MgSO}_{4}$. Filtered and concentrated in vacuo to give $39 \mathrm{mg}$ (87\% yield) of 2-(2-(4-(2-allyl-3-((4-iodothiophen2-yl)oxy)piperidine-3-carbonyl)piperazin-1-yl)phenoxy)ethyl acetate 5a. Steps described in general method 2 were adapted to access intermediate $\mathbf{5 b}$ below and target $\mathbf{5}$.

Preparation of key intermediates $\mathbf{4 a}$ for synthesis of target 4 (Table 1)<smiles>C=CC[C@H]1N(C(=O)c2cnccc2C(F)(F)F)CCC[C@]1(Oc1cc(I)cs1)C(=O)N1CCN(c2ccccc2OCCOC(C)=O)CC1</smiles> 

piperidine-3-carbonyl)piperazin-1-yl)phenoxy)ethyl acetate $5 \mathbf{b}(29 \mathrm{mg}, 0.036 \mathrm{mmol})$ in $\mathrm{MeOH}(1 \mathrm{~mL})$ was added $10 \% \mathrm{Pd} / \mathrm{C}(6 \mathrm{mg}, 20 \% \mathrm{w} / \mathrm{w})$. The reaction mixture purged with $\mathrm{H}_{2}$. After stirring at room temperature $2 \mathrm{~h}$, the mixture was filtered through celite and concentrated in vacuo to give to give $23 \mathrm{mg}$ (94\% yield) of product 2-(2-(4-(2-propyl-3(thiophen-2-yloxy)-1-(4-(trifluoromethyl)nicotinoyl)piperidine-3-carbonyl)piperazin-1yl)phenoxy)ethyl acetate 4a. Steps described in general method 2 were adapted to access target 4 .

Preparation of key intermediate $\mathbf{7 b}$ for synthesis of target 7 (Table 1)

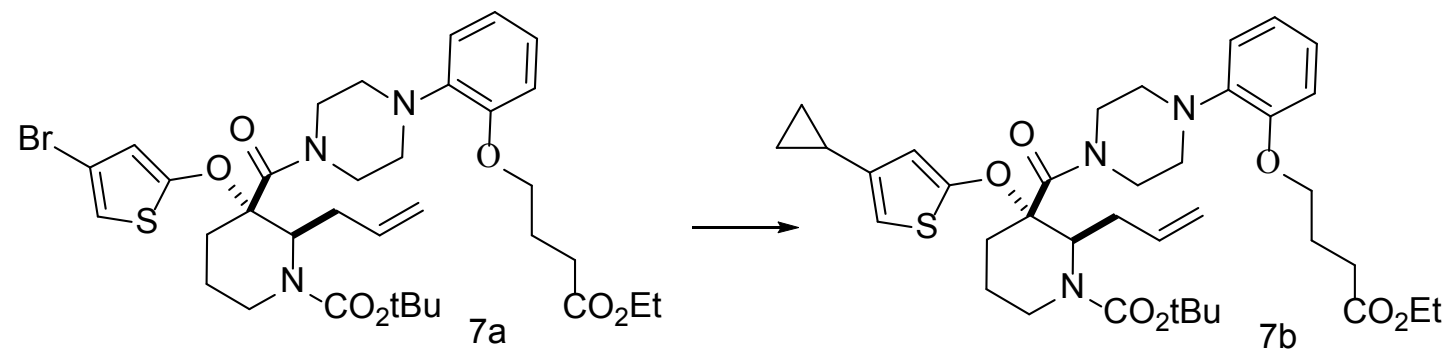

To tert-butyl-2-allyl-3-((4-bromothiophen-2-yl)oxy)-3-(4-(2-(4-ethoxy-4-oxobutoxy)phenyl)piperazine-1-carbonyl)piperidine-1-carboxylate 7a (47 $\mathrm{mg}, 0.065 \mathrm{mmol})$ was added cyclopropyl boronic acid (28 mg, $0.33 \mathrm{mmol}$, 5eq.), $\mathrm{Pd}_{2}(\mathrm{dba})_{3}(6.4 \mathrm{mg}, 0.007$ mmol, 0.1eq.), $\mathrm{tBu}_{3}$ P.HBF 4 (5 mg, $0.016 \mathrm{mmol}, 0.24$ eq.) and KF (15 mg, 0.26mmol, 4eq.) was added dioxane $(3 \mathrm{~mL})$. The mixture was stirred at $90^{\circ} \mathrm{C}$ under $\mathrm{N}_{2}$ for $18 \mathrm{hrs}$. The reaction was diluted with water and extracted with EtOAc. The combined organic layers were washed with brine and dried over $\mathrm{MgSO}$, filtered and concentrated in vacuo to give $49 \mathrm{mg}$ (72\% yield) of tert-butyl-2-allyl-3-((4-cyclopropylthiophen-2-yl)oxy)-3-(4(2-(4-ethoxy-4-oxobutoxy)phenyl)piperazine-1-carbonyl)piperidine-1-carboxylate $\mathbf{7 b}$. Ester hydrolysis described in step 6 of general method 2 was adapted to access target 7.

4-(2-(4-((2R,3S)-2-propyl-1-(4-(trifluoromethyl)nicotinoyl)-3-((5(trifluoromethyl)thiophen-3-yl)oxy)piperidine-3-carbonyl)piperazin-1yl)phenoxy)butanoic acid (21) - general method 1 

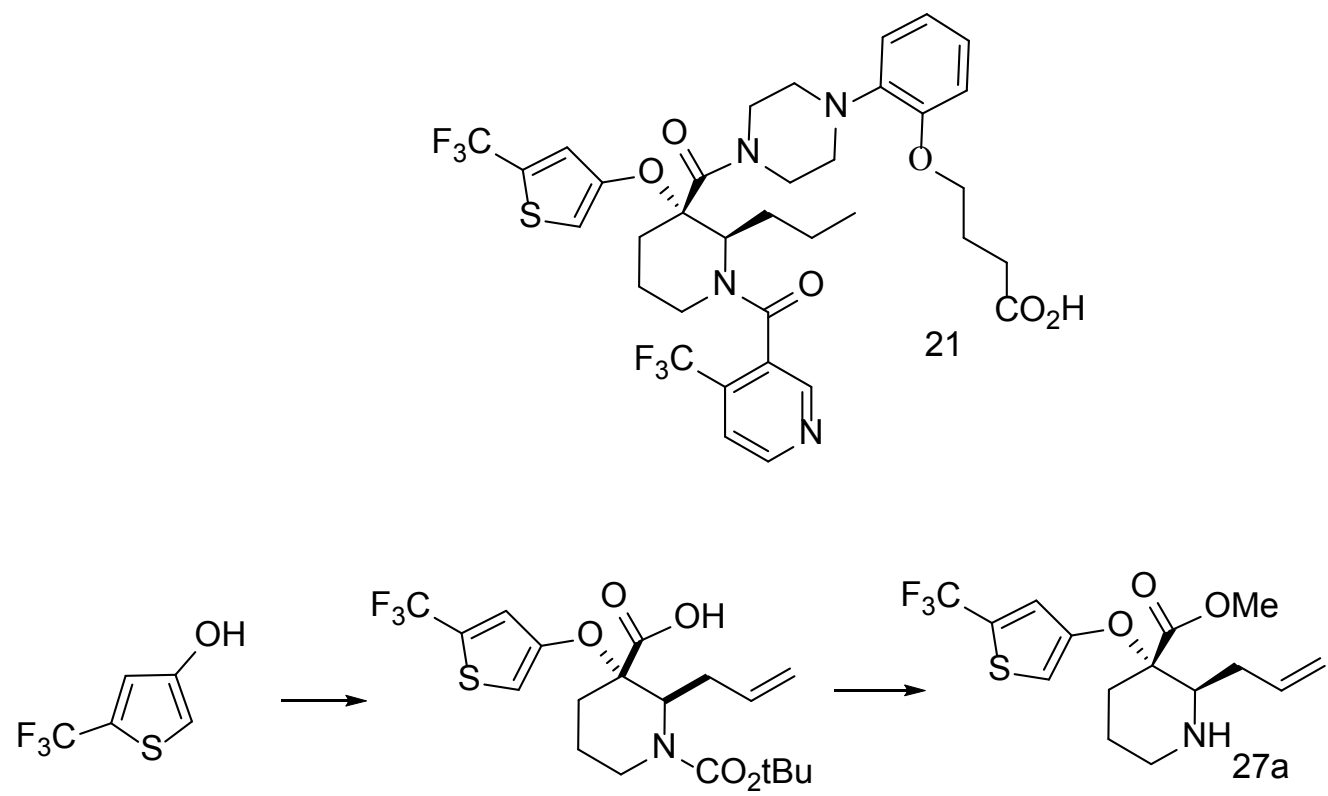

Step 1:

To a solution of $\mathbf{2 6 a}(2.15 \mathrm{~mol}, 507.6 \mathrm{~g}, 1.5 \mathrm{eq})$ in anhydrous THF (6 L) at room temperature under $\mathrm{N}_{2}$ was added $2.3 \mathrm{~L}$ of extra dry chloroform. At $0^{\circ} \mathrm{C}, \mathrm{NaOH}$ (10equiv, 14.3 mol, Beads, 20-40 mesh, $572 \mathrm{~g}$ ) was added in one portion resulting in an orange solution. A solution of 4-hydroxy-2(trifluoromethyl))thiophene (1 eq, $1.43 \mathrm{~mol}, 240 \mathrm{~g}$ ) in THF $(400 \mathrm{~mL})$ was added portion wise in $15 \mathrm{~min}$. The resulting dark orange solution was stirred at room temperature overnight. After 18 hours, the dark brown solution was cooled down to $0^{\circ} \mathrm{C}$ and $\mathrm{MeOH}(600 \mathrm{~mL})$ was slowly added to control internal temperature to $30^{\circ} \mathrm{C}$. Reaction was stirred for 2 hours then water $(3.6 \mathrm{~L})$ was added. While stirring, $\mathrm{pH}$ was adjusted to $\mathrm{pH} 2$ with $3 \mathrm{~N} \mathrm{HCl}(1 \mathrm{~L})$ and the aqueous layer was separated. The aqueous solution was extracted with ethyl acetate $(4 \mathrm{~L})$. The combined extracts were combined, washed with brine (2 L) and dried over $\mathrm{MgSO}_{4}$, filtered and evaporated to dryness to yield 2-allyl-1-(tert-butoxycarbonyl)-3-((5(trifluoromethyl)thiophen-3-yl)oxy)piperidine-3-carboxylic acid as a crude mixture (1.43 mol). LCMS m/z = 457(M+Na)+, 435(M+H)+, 335(M- Boc +H)+.

Step 2:

To a $\quad 10^{\circ} \mathrm{C} \quad$ solution of crude 2-allyl-1-(tert-butoxycarbonyl)-3-((5(trifluoromethyl)thiophen-3-yl)oxy)piperidine-3-carboxylic acid (1.43 mol) in $\mathrm{MeOH}(3$ $\mathrm{L})$ and $\mathrm{CH}_{3} \mathrm{CN}(3 \mathrm{~L})$ was added a $2.0 \mathrm{M}$ solution of TMS-diazomethane (2.86 L, 5.72 mol, 4 eq) over 2 hours. Stirring was maintained at room temperature for 3.6 hours. The 
dark brown solution was concentrated in vacuo. The crude mixture was dissolved in $\mathrm{CH}_{2} \mathrm{Cl}_{2}(1 \mathrm{~L})$ and eluted through a $5 \mathrm{Kg}$ silica gel plug $(95: 5$ hexane/EtOAc) to yield 303 $\mathrm{g}$ of dark oil that was dissolved in $\mathrm{CH}_{2} \mathrm{Cl}_{2}(1.5 \mathrm{~L})$. TFA ( $\left.20 \mathrm{~mol}, 1.5 \mathrm{~L}, 30 \mathrm{eq}\right)$ was added dropwise at room temperature over 1.5 hours and stirring was maintained for an additional 3 hours then was concentrated in vacuo. The residue was taken up into EtOAc (4 L) and water (2 L). While stirring, $\mathrm{pH}$ was adjusted to $\mathrm{pH} 8$ with $\mathrm{NaOH}(1.0 \mathrm{~N})$. The aqueous solution was extracted with ethyl acetate $(4 \mathrm{~L})$. The combined extracts were combined, washed with brine $(2 \mathrm{~L})$ and dried over $\mathrm{MgSO}_{4}$, filtered and evaporated to dryness to yield $224 \mathrm{~g}$ (29\% yield) of methyl 2-allyl-3-((5-(trifluoromethyl)thiophen-3yl)oxy)piperidine-3-carboxylate as a racemic mixture. The enantiomers were separated by chiral HPLC to give $79 \mathrm{~g}$ ( $25 \%$ yield) of the active enantiomer (drawn) methyl (2R,3S)-2-allyl-3-((5-(trifluoromethyl)thiophen-3-yl)oxy)piperidine-3carboxylate $\quad$ 27a (first-eluting peak). The other enantiomer (second-eluting peak) has no activity. LCMS $\mathrm{m} / \mathrm{z}=350.2(\mathrm{M}+\mathrm{H})+.{ }^{1} \mathrm{H}$ NMR $\left(400 \mathrm{MHz}, \mathrm{CDCl}_{3}\right), \delta 7.11(\mathrm{~s}, 1 \mathrm{H}), 6.52(\mathrm{~s}, 1 \mathrm{H}), 5.87-$ $5.77(\mathrm{~m}, 1 \mathrm{H}), 5.13(\mathrm{~d}, J=4.4 \mathrm{~Hz}, 1 \mathrm{H}), 5.10(\mathrm{~s}, 1 \mathrm{H}), 3.77$ (s, 3H), 3.01 (dd, $J=10.4 \mathrm{~Hz}, J$ $=4 \mathrm{~Hz}, 1 \mathrm{H}), 2.96-2.89(\mathrm{~m}, 1 \mathrm{H}), 2.69-2.66(\mathrm{~m}, 1 \mathrm{H}), 2.45-2.42(\mathrm{~m}, 1 \mathrm{H}), 2.33-2.15(\mathrm{~m}$, $2 \mathrm{H}), 1.92-1.86(\mathrm{~m}, 1 \mathrm{H}), 1.83-1.77(\mathrm{~m}, 1 \mathrm{H}), 1.65-1.56(\mathrm{~m}, 1 \mathrm{H})$.

- Chiral HPLC: Column: AD 20 micron; Mobile phase: 90/10 hex/IPA (no additive); Conditions: $80 \mathrm{~mL} \cdot \min 25^{\circ} \mathrm{C}-80 \%$ recovery

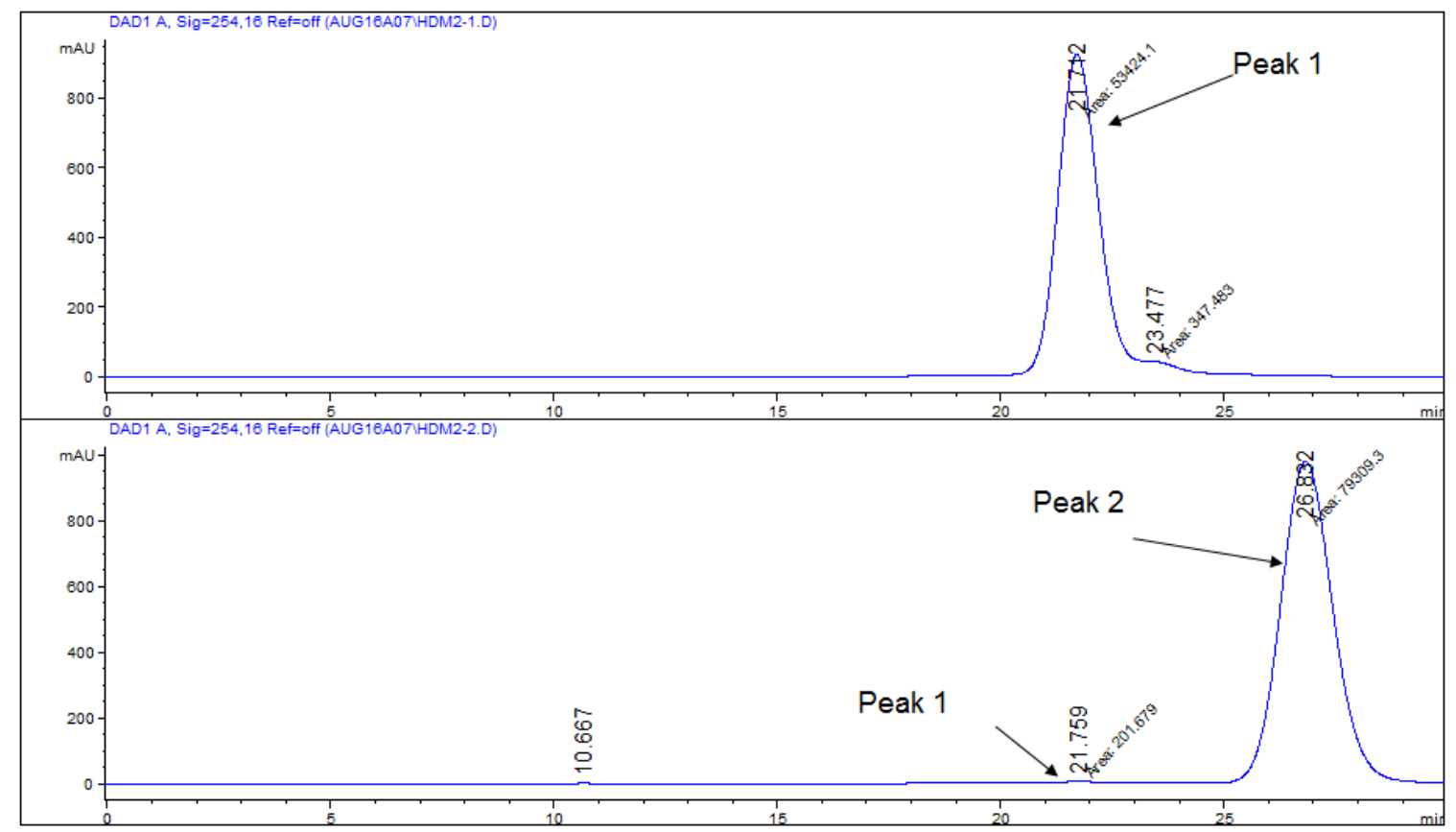




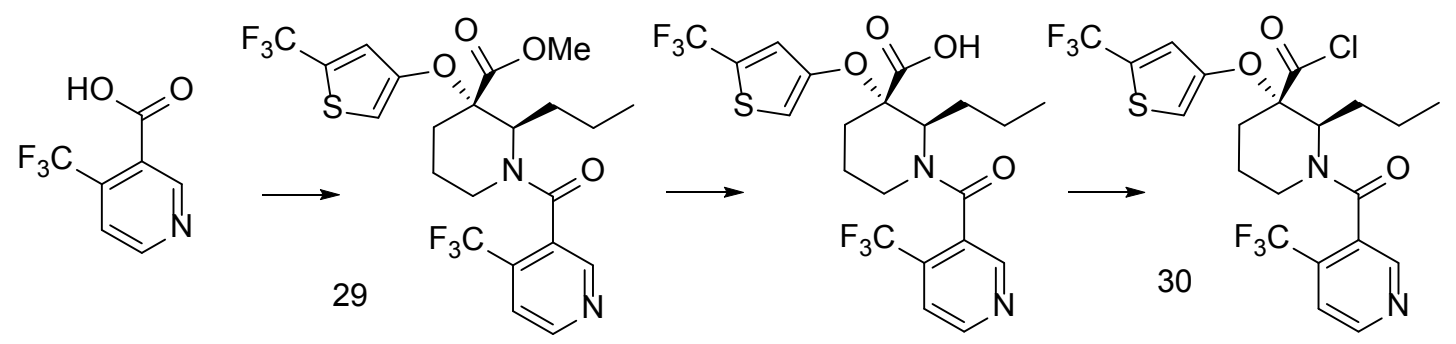

Step 1:

To a room temperature solution of trifluoromethyl nicotinic acid $(172 \mathrm{mmol}, 32.8 \mathrm{~g})$ in benzene $(500 \mathrm{~mL})$ was added thionyl chloride (1.5 equiv, $258 \mathrm{mmol}, 19 \mathrm{~mL}$ ) followed by DMF $(1.5 \mathrm{~mL})$. Reaction was brought to reflux and stirred for $1 \mathrm{~h}$. After cooling down to room temperature, the reaction mixture was concentrated in vacuo to remove excess of reagents. The resulting crude yellow oil was dissolved in $\mathrm{CH}_{2} \mathrm{Cl}_{2}(700 \mathrm{~mL})$ and cooled to $0^{\circ} \mathrm{C}$. To this solution was added $27 \mathrm{a}(143 \mathrm{mmol}, 50 \mathrm{~g})$ in $\mathrm{CH}_{2} \mathrm{Cl}_{2}(300 \mathrm{~mL})$ followed by DIPEA (5equiv, $700 \mathrm{mmol}, 120 \mathrm{~mL}$ ). Stirring was maintained at this temperature for 0.5 hour. The reaction mixture was concentrated in vacuo then taken up into EtOAc (250 $\mathrm{mL}$ ) and washed with $\mathrm{NaHCO}_{3}(250 \mathrm{~mL})$, washed with brine and dried over $\mathrm{MgSO}$, filtered and concentrated in vacuo to give $75 \mathrm{~g}$ (100\% yield) of methyl (2R,3S)-2-allyl-1(4-(trifluoromethyl)nicotinoyl)-3-((5-(trifluoromethyl)thiophen-3-yl)oxy)piperidine-3carboxylate. LCMS m/z $=523.4(\mathrm{M}+\mathrm{H})+$.

To a stirring solution of methyl (2R,3S)-2-allyl-1-(4-(trifluoromethyl)nicotinoyl)-3-((5(trifluoromethyl)thiophen-3-yl)oxy)piperidine-3-carboxylate $(0.94 \mathrm{~g}, 1.80 \mathrm{mmol})$ in EtOH $(20 \mathrm{~mL})$ was added $10 \% \mathrm{Pd} / \mathrm{C}(188 \mathrm{mg}, 20 \% \mathrm{w} / \mathrm{w})$ and the reaction mixture purged with $\mathrm{H}_{2}$. After stirring at room temperature $2 \mathrm{~h}$, the mixture was filtered through celite and concentrated in vacuo to give methyl (2R,3S)-2-propyl-1-(4(trifluoromethyl)nicotinoyl)-3-((5-(trifluoromethyl)thiophen-3-yl)oxy)piperidine-3carboxylate 29 ( $0.95 \mathrm{~g}, 100 \%$ yield $).$ LCMS m/z $=525.4(\mathrm{M}+\mathrm{H})+.{ }^{1} \mathrm{H}$ NMR $(400 \mathrm{MHz}$, $\mathrm{CDCl}_{3}$ - mixture of rotamers), $\delta 8.84(\mathrm{bs}, 1 \mathrm{H}), 8.72(\mathrm{~s}, 0.5 \mathrm{H}), 8.59(\mathrm{~s}, 0.5 \mathrm{H}), 7.64-7.59$ $(\mathrm{m}, 1 \mathrm{H}), 7.26(\mathrm{~s}, 0.5 \mathrm{H}), 7.11(\mathrm{~s}, 0.5 \mathrm{H}), 6.54(\mathrm{~s}, 0.5 \mathrm{H}), 6.45(\mathrm{~s}, 0.5 \mathrm{H}), 5.42-5.33(\mathrm{~m}, 1 \mathrm{H})$, $3.81(\mathrm{~s}, 1.5 \mathrm{H}), 3.79(\mathrm{~s}, 1.5 \mathrm{H}), 3.10-3.13(\mathrm{~m}, 2 \mathrm{H}), 2.48-2.41(\mathrm{~m}, 1 \mathrm{H}), 2.18-2.08(\mathrm{~m}, 1 \mathrm{H})$, $1.86-1.73(\mathrm{~m}, 1 \mathrm{H}), 1.67-1.57(\mathrm{~m}, 1 \mathrm{H}), 1.52-1.42(\mathrm{~m}, 3 \mathrm{H}), 1.26-1.18(\mathrm{~m}, 2 \mathrm{H}), 1.03(\mathrm{t}, J=$ $7.2 \mathrm{~Hz}, 1.5 \mathrm{H}), 0.98$ (t, $J=7.2 \mathrm{~Hz}, 1.5 \mathrm{H})$.

Step 2: 
To 29 ( $0.9 \mathrm{~g}, 1.78 \mathrm{mmol})$ in aqueous $\mathrm{KOH}(7.6 \mathrm{~mL}, 26.6 \mathrm{mmol}$, 15 equiv) was added $\mathrm{MeOH}(11.4 \mathrm{~mL})$. Reaction was brought to $60^{\circ} \mathrm{C}$ and stiired overnight. After 18 hours, reaction mixture was concentrated down in vacuo to remove $\mathrm{MeOH}$. The residue was diluted with water $(10 \mathrm{~mL})$ and $\mathrm{pH}$ was adjusted to $\mathrm{pH} 3.5$ using $1.0 \mathrm{~N} \mathrm{HCl}$. EtOAc (25 $\mathrm{mL}$ ) was added and aqueous layer was extracted twice. The combined extracts were washed with brine and dried over $\mathrm{MgSO}_{4}$, filtered and evaporated to dryness to give (2R,3S)-2-propyl-1-(4-(trifluoromethyl)nicotinoyl)-3-((5-(trifluoromethyl)thiophen-3yl)oxy)piperidine-3-carboxylic acid (0.9 g). LCMS m/z $=511.1(\mathrm{M}+\mathrm{H})+{ }^{1}{ }^{1} \mathrm{H}$ NMR $(400$ $\mathrm{MHz}, \mathrm{CDCl}_{3}$ - mixture of rotamers), $\delta 8.87$ (bs, $\left.1 \mathrm{H}\right), 8.76(\mathrm{~s}, 0.5 \mathrm{H}), 8.60(\mathrm{~s}, 0.5 \mathrm{H}), 7.69$ $7.65(\mathrm{~m}, 1 \mathrm{H}), 7.26(\mathrm{~s}, 0.5 \mathrm{H}), 7.16(\mathrm{~s}, 0.5 \mathrm{H}), 6.68(\mathrm{~s}, 0.5 \mathrm{H}), 6.45(\mathrm{~s}, 0.5 \mathrm{H}), 5.43-5.37(\mathrm{~m}$, $1 \mathrm{H}), 3.21-3.13(\mathrm{~m}, 2 \mathrm{H}), 2.41-2.37(\mathrm{~m}, 1 \mathrm{H}), 2.17-2.14(\mathrm{~m}, 1 \mathrm{H}), 1.85-1.76(\mathrm{~m}, 1 \mathrm{H}), 1.62-$ $1.59(\mathrm{~m}, 1 \mathrm{H}), 1.50-1.27(\mathrm{~m}, 5 \mathrm{H}), 1.01-0.94(\mathrm{~m}, 3 \mathrm{H})$.

Step 3:

To a $\quad 0^{\circ} \mathrm{C}$ solution of (2R,3S)-2-propyl-1-(4-(trifluoromethyl)nicotinoyl)-3-((5(trifluoromethyl)thiophen-3-yl)oxy)piperidine-3-carboxylic acid (140 mmol, $75 \mathrm{~g})$ in $\mathrm{CH}_{2} \mathrm{Cl}_{2}(800 \mathrm{~mL})$ was added DMF $(1 \mathrm{~mL})$ followed by a slow addition of oxalyl chloride $(25 \mathrm{~mL}, 280 \mathrm{mmol})$. After 1 hour, reaction mixture turned into slurry. A small aliquot diluted in $\mathrm{MeOH}$ showed LCMS m/z $=525.4(\mathrm{M}+\mathrm{H})+$, indication of complete conversion to corresponding methyl ester 29. Without $\mathrm{MeOH}$ treatment, LCMS m/z $=529(\mathrm{M}+\mathrm{H})+$ was detected as well as a minor $\operatorname{LCMS} \mathrm{m} / \mathrm{z}=511.1(\mathrm{M}+\mathrm{H})+$ for the corresponding carboxylic acid (hydrolysis prodruct during LCMS run). The reaction mixture was concentrated in vacuo and dry under high vacuum for 18 hours to provide (2R,3S)-2propyl-1-(4-(trifluoromethyl)nicotinoyl)-3-((5-(trifluoromethyl)thiophen-3-

yl)oxy)piperidine-3-carbonyl chloride $\mathbf{3 0}$ in quantitative yield. Compound $\mathbf{3 0}$ was used without further purification. 


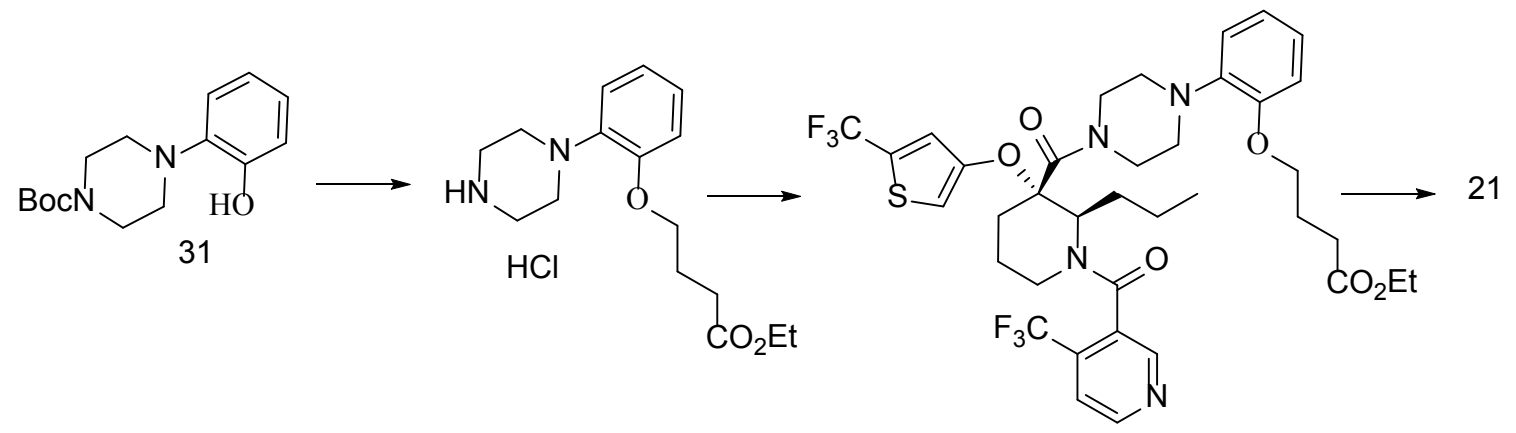

Step1:

To a RT solution of commercially available tert-butyl 4-(2-hydroxyphenyl)piperazine-1carboxylate 31 (88 g, $314 \mathrm{mmol})$ in DMF $(900 \mathrm{~mL})$ was added potassium carbonate $(86.6$ g, $627.6 \mathrm{mmol}, 2 \mathrm{eq})$ and ethyl bromobutyrate $(471 \mathrm{mmol}, 67 \mathrm{~mL}, 1.5 \mathrm{eq})$. This reaction was stirred for 48 hours at room temperature. The reaction mixture was concentrated to half its volume, and then diluted with EtOAc $(2 \mathrm{~L})$ and water $(1 \mathrm{~L})$. The organic phase was washed $4 \mathrm{X}$ with water $(1 \mathrm{~L})$ to remove DMF, was then washed $4 \mathrm{X}$ with brine, dried over sodium sulfate, and concentrated in vacuo. The crude mixture was eluted through a $0.6 \mathrm{Kg}$ silica gel plug (95:5 to 40:60 hexane/EtOAc) to yield tert-butyl 4-(2-(4-ethoxy-4oxobutoxy)phenyl)piperazine-1-carboxylate $(95.1 \mathrm{~g})$ to which was added a solution of 4.0 $\mathrm{M} \mathrm{HCl}$ in dioxane, $(500 \mathrm{~mL}, 8 \mathrm{eq})$. After 20 minutes, the reaction mixture was concentrated in vacuo to a white solid. The product was partially dissolved in $\mathrm{CH}_{2} \mathrm{Cl}_{2}$, and precipitated with hexane and filtered. The cake was washed with hexane $(3 x)$ and dried under vacuum to give ethyl 4-(2-(piperazin-1-yl)phenoxy)butanoate hydrochloride as a powdery white solid (86 g). ${ }^{1} \mathrm{H}$ NMR (400 MHz, Dimethyl Sulfoxide- $\left.\mathrm{d}_{6}\right), \delta$ 6.99$6.87(\mathrm{~m}, 4 \mathrm{H}), 4.06$ (q, $J=1.2 \mathrm{~Hz}, 2 \mathrm{H}), 3.97$ (t, $J=5.6 \mathrm{~Hz}, 2 \mathrm{H}), 3.19$ (bs, 4H), 1.99-1.96 $(\mathrm{m}, 2 \mathrm{H}), 1.14(\mathrm{t}, J=5.2 \mathrm{~Hz}, 3 \mathrm{H})$.

Step 2:

To a $0^{\circ} \mathrm{C}$ stirring solution of acid chloride $30(140 \mathrm{mmol})$ in $\mathrm{DCM}(800 \mathrm{~mL})$ was added ethyl 4-(2-(piperazin-1-yl)phenoxy)butanoate hydrochloride prepared above (168 mmol, $61 \mathrm{~g}, 1.2$ equiv) followed by DIPEA ( $420 \mathrm{mmol}, 74 \mathrm{~mL}, 3 \mathrm{eq}$ ). After 2 hours the reaction mixture was concentrated in vacuo to a smaller volume. The residue was taken up into EtOAc $(1 \mathrm{~L})$ and water $(1 \mathrm{~L})$. The organic layer was washed with $\mathrm{NaHCO}_{3}$ then $\mathrm{HCl}$ $(1.0 \mathrm{~N})$. The combined extracts were washed with brine and dried over $\mathrm{MgSO}_{4}$, filtered and concentrated in vacuo. The crude mixture was eluted through a $1 \mathrm{Kg}$ silica gel plug 
(9:1 to $1: 1$ hexane/EtOAc) to yield after high vaccum ethyl 4-(2-(4-((2R,3S)-2-propyl-1(4-(trifluoromethyl)nicotinoyl)-3-((5-(trifluoromethyl)thiophen-3-yl)oxy)piperidine-3carbonyl)piperazin-1-yl)phenoxy)butanoate (96 g, 87\% yield). LCMS m/z $=785.4$ $(\mathrm{M}+\mathrm{H})+{ }^{1} \mathrm{H}$ NMR $\left(400 \mathrm{MHz}, \mathrm{CDCl}_{3}-\right.$ mixture of rotamers), $\delta 8.87-8.85(\mathrm{~m}, 1 \mathrm{H}), 8.77$ (s, 0.5H), $8.60(\mathrm{~s}, 0.5 \mathrm{H}), 7.64-7.63(\mathrm{~m}, 1 \mathrm{H}), 7.17(\mathrm{~s}, 0.5 \mathrm{H}), 7.13(\mathrm{~s}, 0.5 \mathrm{H}), 7.01-6.78(\mathrm{~m}$, $4 \mathrm{H}), 6.57(\mathrm{~s}, 0.5 \mathrm{H}), 6.53(\mathrm{~s}, 0.5 \mathrm{H}), 5.54-5.51(\mathrm{~m}, 1 \mathrm{H}), 4.20-4-06(\mathrm{~m}, 6 \mathrm{H}), 4.04-3.83(\mathrm{~m}$, $2 \mathrm{H}), 3.17-2.94(\mathrm{~m}, 5 \mathrm{H}), 2.68-2.66(\mathrm{~m}, 1 \mathrm{H}), 2.58-2.51(\mathrm{~m}, 3 \mathrm{H}), 2.42-2.36(\mathrm{~m}, 1 \mathrm{H}), 2.20-$ $2.12(\mathrm{~m}, 2 \mathrm{H}), 1.98-1.90(\mathrm{~m}, 1 \mathrm{H}), 1.68-1.44(\mathrm{~m}, 5 \mathrm{H}), 1.28-1.23(\mathrm{~m}, 3 \mathrm{H}), 1.04-1.00(\mathrm{~m}$, $3 \mathrm{H})$.

Step 3:

To a room temperature solution of ester $(18 \mathrm{~g})$ in $\mathrm{MeOH}(180 \mathrm{~mL})$ was added $\mathrm{KOH}(3.5$ $\mathrm{N}, 65 \mathrm{~mL}, 10 \mathrm{eq}$ ). After 2 hours, both TLC and MS indicated completion. Reaction was concentrated down under vacuo to remove most of $\mathrm{MeOH}$, taken up in EtOAc $(250 \mathrm{~mL})$ and washed with $\mathrm{NH}_{4} \mathrm{Cl}$ then brine. Organic layer was dried over $\mathrm{MgSO} 4$, filtered and concentrated down under vacuo to yield 4-(2-(4-((2R,3S)-2-propyl-1-(4(trifluoromethyl)nicotinoyl)-3-((5-(trifluoromethyl)thiophen-3-yl)oxy)piperidine-3carbonyl)piperazin-1-yl)phenoxy)butanoic acid 21 (16.9 g). $16.6 \mathrm{~g}$ of 21 were dissolved in DCM $(250 \mathrm{~mL})$ and hexane (125 mL.) Under stirring, $\mathrm{HCl}$ (2.0 M in $\mathrm{Et}_{2} \mathrm{O}, 10$ eq, 200 $\mathrm{mmol}, 100 \mathrm{~mL}$ ) was added and the white precipitate was stirred at high speed for $1 \mathrm{~h}$. The slurry was filtrated and cake dried under nitrogen stream. In a 1L Beaker was added the $\mathrm{HCl}$ salt $(18 \mathrm{~g})$ followed by acetone $(300 \mathrm{~mL})$. Slurry was stirred for 10 minutes to complete dissolution. The clear solution was filtered through frit funnel. Under stirring, water was added to the filtrate until persistent turbidity was observed. After 18 hours stirring was stopped and $14.55 \mathrm{~g}$ (84\% recovery) of crystalline 21 (free form) was isolated after filtration. $\mathrm{mp}=190-195^{\circ} \mathrm{C} . \mathrm{LCMS} \mathrm{m} / \mathrm{z}=757.4(\mathrm{M}+\mathrm{H})+.{ }^{1} \mathrm{H}$ NMR $(400$ $\mathrm{MHz}, \mathrm{CDCl}_{3}$ - mixture of rotamers), $\delta 8.87(\mathrm{~s}, 1 \mathrm{H}), 8.77(\mathrm{~s}, 0.5 \mathrm{H}), 8.61(\mathrm{~s}, 0.5 \mathrm{H}), 7.69$ $7.60(\mathrm{~m}, 1 \mathrm{H}), 7.18(\mathrm{~s}, 0.5 \mathrm{H}), 7.11(\mathrm{~s}, 0.5 \mathrm{H}), 7.02-6.94(\mathrm{~m}, 1 \mathrm{H}), 6.93-6.82(\mathrm{~m}, 3 \mathrm{H}), 6.80-$ $6.72(\mathrm{~m}, 1 \mathrm{H}), 6.56(\mathrm{~m}, 0.5 \mathrm{H}), 6.54(\mathrm{~m}, 0.5 \mathrm{H}), 5.53(\mathrm{~s}, 1 \mathrm{H}), 4.39-4.19(\mathrm{~m}, 2 \mathrm{H}), 4.17-3.98$ (m, 3H), 3.77-3.58 (m, 1H), 3.28-3.04 (m, 4H), 3.77-3.58 (m, 1H), 2.97-2.80 (m, 1H), 2.67-2.34 (m, 5H), 2.30-2.07 (m, 3H), 1.98-1.86 (m, 1H), 1.66-1.36 (m, 4H), 1.08-0.97 $(\mathrm{m}, 3 \mathrm{H})$. 
Characterization data for targets: $3,4,8,10,14,15,17,18,19,22,24$.

(4-(2-(2-hydroxyethoxy)phenyl)piperazin-1-yl)((2R,3S)-2-propyl-1-(4-

(trifluoromethyl)nicotinoyl)-3-(4-(trifluoromethyl)phenoxy)piperidin-3-yl)methanone 3 . LCMS m/z $=709.5(\mathrm{M}+\mathrm{H})+.{ }^{1} \mathrm{H}$ NMR $\left(500 \mathrm{MHz}\right.$, Dimethyl Sulfoxide- $\mathrm{d}_{6}$, mixture of rotamers), $\delta 8.98(\mathrm{bs}, 1 \mathrm{H}), 8.68(\mathrm{~s}, 1 \mathrm{H}), 8.77(\mathrm{~s}, 1 \mathrm{H}), 7.93(\mathrm{bs}, 1 \mathrm{H}), 7.62-7.59(\mathrm{~m}, 2 \mathrm{H})$, 7.13(bs, 1H), 6.99-6.97 (m, 1H), 6.95-6.92 (m, 2H), 6.89-6.81 (m, 1H), $6.71(\mathrm{dd}, J=$ $5.0 \mathrm{~Hz} \& J=16.5 \mathrm{~Hz}, 1 \mathrm{H}), 5.38(\mathrm{~d}, J=12.0 \mathrm{~Hz}, 1 \mathrm{H}), 4.16-3.66(\mathrm{~m}, 6 \mathrm{H}), 3.29-2.78(\mathrm{~m}$, $6 \mathrm{H}), 2.32-2.46(\mathrm{~m}, 3 \mathrm{H}), 2.06-1.96(\mathrm{~m}, 1 \mathrm{H}), 1.57-1.16(\mathrm{~m}, 6 \mathrm{H}), 1.02-0.94(\mathrm{~m}, 3 \mathrm{H})$.

(4-(2-(2-hydroxyethoxy)phenyl)piperazin-1-yl)(2-propyl-3-(thiophen-2-yloxy)-1-(4-

(trifluoromethyl)nicotinoyl)piperidin-3-yl)methanone 4. LCMS m/z $=646.7(\mathrm{M}+\mathrm{H})+.{ }^{1} \mathrm{H}$ NMR (400 MHz, $\mathrm{CDCl}_{3}$ - mixture of rotamers), $\delta 7.16(\mathrm{~s}, 1 \mathrm{H}), 7.10(\mathrm{~s}, 1 \mathrm{H}), 6.99(\mathrm{t}, J=$ $7.3 \mathrm{~Hz}, 1 \mathrm{H}), 6.93-6.85(\mathrm{~m}, 3 \mathrm{H}), 6.81-6.78(\mathrm{~m}, 1 \mathrm{H}), 6.31(\mathrm{dd}, J=1.4 \mathrm{~Hz} \& J=3.8 \mathrm{~Hz}, 1 \mathrm{H})$, $6.06(\mathrm{~s}, 1 \mathrm{H}), 5.54(\mathrm{~d}, J=11.7 \mathrm{~Hz}, 1 \mathrm{H}), 5.44-5.34(\mathrm{~m}, 1 \mathrm{H}), 4.14-3.98(\mathrm{~m}, 5 \mathrm{H}), 3.78-3.68$ $(\mathrm{m}, 1 \mathrm{H}), 3.22-3.06(\mathrm{~m}, 5 \mathrm{H}), 2.96-2.86(\mathrm{~m}, 1 \mathrm{H}), 2.58-2.36(\mathrm{~m}, 6 \mathrm{H}), 2.24-2.14(\mathrm{~m}, 3 \mathrm{H})$, $1.60-1.36(\mathrm{~m}, 5 \mathrm{H}), 1.25(\mathrm{t}, J=7.3 \mathrm{~Hz}, 1 \mathrm{H}), 1.06-0.96(\mathrm{~m}, 4 \mathrm{H})$.

(4-(2-(2-hydroxyethoxy)phenyl)piperazin-1-yl)(2-propyl-1-(4(trifluoromethyl)nicotinoyl)-3-((4-(trifluoromethyl)thiazol-2-yl)oxy)piperidin-3yl)methanone 8. LCMS m/z $=716.6(\mathrm{M}+\mathrm{H})+.{ }^{1} \mathrm{H}$ NMR $\left(400 \mathrm{MHz}, \mathrm{CDCl}_{3}-\right.$ mixture of rotamers), $\delta 8.86(\mathrm{~s}, 1 \mathrm{H}), 8.73(\mathrm{~s}, 0.5 \mathrm{H}), 8.61(\mathrm{~s}, 0.5 \mathrm{H}), 7.64(\mathrm{~d}, J=4.8 \mathrm{~Hz}$, $1 \mathrm{H}), 7.23(\mathrm{~s}, 0.5 \mathrm{H}), 7.18(\mathrm{~s}, 0.5 \mathrm{H}), 7.10-6.95(\mathrm{~m}, 3 \mathrm{H}), 6.87-6.81(\mathrm{~m}, 1 \mathrm{H})$, $5.49(\mathrm{~d}, J=15 \mathrm{~Hz}, 1 \mathrm{H}), 4.30-3.91(\mathrm{~m}, 5 \mathrm{H}), 3.81-3.53(\mathrm{~m}, 3 \mathrm{H}), 3.28-2.77$ $(\mathrm{m}, 7 \mathrm{H}), 2.59-2.41(\mathrm{~m}, 2 \mathrm{H}), 2.38-2.27(\mathrm{~m}, 1 \mathrm{H}), 1.97-1.82(\mathrm{~m}, 1 \mathrm{H}), 1.63-$ $1.37(\mathrm{~m}, 5 \mathrm{H}), \quad 1.08-0.97(\mathrm{~m}, 3 \mathrm{H})$.

(4-(2-(2-hydroxyethoxy)phenyl)piperazin-1-yl)((2R,3S)-2-propyl-1-(4(trifluoromethyl)nicotinoyl)-3-((5-(trifluoromethyl)thiophen-3-yl)oxy)piperidin-3yl)methanone 10. LCMS m/z $=715.4(\mathrm{M}+\mathrm{H})+$. ${ }^{1} \mathrm{H} \mathrm{NMR}\left(400 \mathrm{MHz}, \mathrm{CDCl}_{3}-\right.$ mixture of rotamers), $\delta$ 8.95-8.63-8.95 (m, 1H), $7.71(\mathrm{~s}, 1 \mathrm{H}), 7.23(\mathrm{~s}, 1 \mathrm{H}), 7.18(\mathrm{~s}, 1 \mathrm{H}), 7.16-7.02$ 
(m, 2H), 6.89-6.85 (m, 1H), $6.60(\mathrm{dd}, J=1.6 \mathrm{~Hz} \& J=16 \mathrm{~Hz}, 1 \mathrm{H}), 5.55(\mathrm{~d}, J=10 \mathrm{~Hz}$, $1 \mathrm{H})$, 4.29-4.13 (m, 2H), 3.87-3.72 (m, 2H), 3.32-3.10 (m, 4H), 2.75-2.37 (m, 4H), 1.89$1.67(\mathrm{~m}, 5 \mathrm{H}), 1.52-1.40(\mathrm{~m}, 5 \mathrm{H}), 1.13-1.03(\mathrm{~m}, 3 \mathrm{H})$.

(4-(2-(2-hydroxyethoxy)phenyl)piperazin-1-yl)((2R,3S)-3-((2-methyl-5(trifluoromethyl)thiophen-3-yl)oxy)-2-propyl-1-(4-(trifluoromethyl)nicotinoyl)piperidin3-yl)methanone 14. LCMS m/z $=729.4(\mathrm{M}+\mathrm{H})+.{ }^{1} \mathrm{H} \mathrm{NMR}\left(400 \mathrm{MHz}, \mathrm{CDCl}_{3}\right.$ - mixture of rotamers), $\delta 8.85(\mathrm{~d}, J=4.8 \mathrm{~Hz}, 1 \mathrm{H}), 8.77(\mathrm{~s}, 1 \mathrm{H}), 7.64(\mathrm{~d}, J=5.2 \mathrm{~Hz}$, $1 \mathrm{H}), 7.16-7.08(\mathrm{~m}, 1 \mathrm{H}), 7.97-7.08(\mathrm{~m}, 3 \mathrm{H}), 6.85-6.77(\mathrm{~m}, 1 \mathrm{H}), 5.50(\mathrm{t}, J$ $=10 \mathrm{~Hz}, 1 \mathrm{H}), 4.27-4.19(\mathrm{~m}, 1 \mathrm{H}), 4.17-4.08(\mathrm{~m}, 2 \mathrm{H}), 3.82-3.70(\mathrm{~m}, 2 \mathrm{H})$, 3.69-3.58 (m, 2H), 3.26-3.11 (m, 3H), 2.53-2.19 (m,7H), $2.04(\mathrm{~s}, 2 \mathrm{H})$, 1.54-1.35 (m, 3H), 1.29-1.19 (m, 3H), 1.07-0.95 (m, 3H).

(4-(2-((1-hydroxy-2-methylpropan-2-yl)oxy)phenyl)piperazin-1-yl)((2R,3S)-2-propyl-1(4-(trifluoromethyl)nicotinoyl)-3-((5-(trifluoromethyl)thiophen-3-yl)oxy)piperidin-3yl)methanone 15. LCMS m/z $=743.6(\mathrm{M}+\mathrm{H})+{ }^{1} \mathrm{H}$ NMR $\left(400 \mathrm{MHz}, \mathrm{CDCl}_{3}-\right.$ mixture of rotamers), $\delta 7.86(\mathrm{~s}, 3 \mathrm{H}), 7.83(\mathrm{~s}, 1 \mathrm{H}), 7.41-7.32(\mathrm{~m}, 1 \mathrm{H}), 7.24-7.10(\mathrm{~m}$, $2 \mathrm{H}), 6.93(\mathrm{~d}, J=7.2 \mathrm{~Hz}, 1 \mathrm{H}), 6.67(\mathrm{~s}, 1 \mathrm{H}), 6.57(\mathrm{~s}, 1 \mathrm{H}), 5.44(\mathrm{~d}, J=12$ $\mathrm{Hz}, 1 \mathrm{H}), 4.29-4.00(\mathrm{~m}, 1 \mathrm{H}), 3.86-3.66(\mathrm{~m}, 2 \mathrm{H}), 3.52(\mathrm{~s}, 2 \mathrm{H}), 3.46-3.32$ $(\mathrm{m}, 1 \mathrm{H}), \quad 3.30-2.9(\mathrm{~m}, 3 \mathrm{H}), 2.59-2.30(\mathrm{~m}, 3 \mathrm{H}), 1.99-1.81(\mathrm{~m}, 1 \mathrm{H}), 1.78-$ $1.63(\mathrm{~m}, 2 \mathrm{H}), 1.59-1.43(\mathrm{~m}, 3 \mathrm{H}), 1.39(\mathrm{~s}, 3 \mathrm{H}), 1.38(\mathrm{~s}, 3 \mathrm{H}), 1.25(\mathrm{~s}, 1 \mathrm{H})$, 1.07-0.94 (m, 3H).

2-(2-(4-((2R,3S)-2-propyl-1-(4-(trifluoromethyl)nicotinoyl)-3-((5-

(trifluoromethyl)thiophen-3-yl)oxy)piperidine-3-carbonyl)piperazin-1-yl)phenoxy)acetic acid 17. $\mathrm{LCMS} \mathrm{m} / \mathrm{z}=729.2(\mathrm{M}+\mathrm{H})+{ }^{1} \mathrm{H}$ NMR $\left(400 \mathrm{MHz}, \mathrm{CDCl}_{3}\right.$ - mixture of rotamers), $\delta 8.89-8.84(\mathrm{~m}, 1 \mathrm{H}), 8.75(\mathrm{~s}, 0.5 \mathrm{H}), 8.60(\mathrm{~s}, 0.5 \mathrm{H}), 7.66-7.61(\mathrm{~m}, 2 \mathrm{H})$, 7.19-7.07 (m, 3H), 7.04-6.92 (m, 1H), 6.59-6.51 (m, 1H), 4.71(d, $J=2.8$ $\mathrm{Hz}, 2 \mathrm{H}), 3.89-3.52(\mathrm{~m}, 3 \mathrm{H}), 3.88-3.06(\mathrm{~m}, 4 \mathrm{H}), 2.64-2.37(\mathrm{~m}, 4 \mathrm{H}), 1.87-$ $1.46(\mathrm{~m}, 8 \mathrm{H}), 1.10-0.98(\mathrm{~m}, 3 \mathrm{H})$. 
N-methyl-2-(2-(4-((2R,3S)-2-propyl-1-(4-(trifluoromethyl)nicotinoyl)-3-((5(trifluoromethyl)thiophen-3-yl)oxy)piperidine-3-carbonyl)piperazin-1yl)phenoxy)acetamide 18. LCMS m/z $=742.2(\mathrm{M}+\mathrm{H})+{ }^{1} \mathrm{H}$ NMR $\left(400 \mathrm{MHz}, \mathrm{CDCl}_{3}\right.$ mixture of rotamers), $\delta 7.76(\mathrm{~s}, 1 \mathrm{H}), 7.13-6.99(\mathrm{~m}, 3 \mathrm{H}), 6.96-6.90(\mathrm{~m}, 2 \mathrm{H})$, 6.88-6.80 (m, 1H), 6.60-6.51 (m, 1H), $5.51(\mathrm{~d}, J=12 \mathrm{~Hz}, 1 \mathrm{H}), 4.60(\mathrm{~d}, J$ $=3.2 \mathrm{~Hz}, 1 \mathrm{H}), 4.29-4.15(\mathrm{~m}, 2 \mathrm{H}), 3.24-3.01(\mathrm{~m}, 5 \mathrm{H}), 2.90-2.87(\mathrm{~m}, 2 \mathrm{H})$, $2.80(\mathrm{dd}, J=2 \mathrm{~Hz} \& 5.6 \mathrm{~Hz}, 2 \mathrm{H}), 2.71-2.46(\mathrm{~m}, 4 \mathrm{H}), 2.44-2.30(\mathrm{~m}, 2 \mathrm{H})$, $1.63-1.34(\mathrm{~m}, 6 \mathrm{H}), 1.01-0.94(\mathrm{~m}, 3 \mathrm{H})$.

2-methyl-2-(2-(4-((2R,3S)-2-propyl-1-(4-(trifluoromethyl)nicotinoyl)-3-((5(trifluoromethyl)thiophen-3-yl)oxy)piperidine-3-carbonyl)piperazin-1yl)phenoxy)propanoic acid 19. LCMS m/z $=757.4(\mathrm{M}+\mathrm{H})+.{ }^{1} \mathrm{H} \mathrm{NMR}\left(400 \mathrm{MHz}, \mathrm{CDCl}_{3}\right.$ - mixture of rotamers), $\delta 9.22-8.53(\mathrm{~m}, 2 \mathrm{H}), 7.88-7.36(\mathrm{~m}, 3 \mathrm{H}), 7.23-6.93(\mathrm{~m}$, $2 \mathrm{H}), 6.85-6.44(\mathrm{~m}, 1 \mathrm{H}), 5.46(\mathrm{~s}, 1 \mathrm{H}), 3.81-3.43(\mathrm{~m}, 4 \mathrm{H}), 3.39-2.96(\mathrm{~m}$, $4 \mathrm{H}), 2.71-2.24(\mathrm{~m}, 4 \mathrm{H}), 1.86(\mathrm{~s}, 6 \mathrm{H}), 1.66-1.20(\mathrm{~m}, 8 \mathrm{H}), 1.08-0.97(\mathrm{~m}, 3 \mathrm{H})$.

2,2-dimethyl-4-(2-(4-((2R,3S)-2-propyl-1-(4-(trifluoromethyl)nicotinoyl)-3-((5(trifluoromethyl)thiophen-3-yl)oxy)piperidine-3-carbonyl)piperazin-1yl)phenoxy)butanoic acid 22. LCMS m/z $=785.4(\mathrm{M}+\mathrm{H})+{ }^{1} \mathrm{H}$ NMR $\left(400 \mathrm{MHz}, \mathrm{CDCl}_{3}\right.$ mixture of rotamers), $\delta 8.08(\mathrm{~s}, 1 \mathrm{H}), 8.01-7.93(\mathrm{~m}, 2 \mathrm{H}), 7.52-7.38(\mathrm{~m}, 4 \mathrm{H})$, $7.15(\mathrm{~s}, 2 \mathrm{H}), 5.30-5.29(\mathrm{~m}, 2 \mathrm{H}), 4.12-4.09(\mathrm{~m}, 3 \mathrm{H}), 4.02-3.88(\mathrm{~m}, 2 \mathrm{H})$, 3.61-3.31 (m, 2H), 3.07-2.89 (m, 3H), 2.58-2.48 (m, 3H), $2.47(\mathrm{~s}, 6 \mathrm{H})$, 2.45-2.31 (m, 3H), 1.61-1.37 (m, 6H), 1.08-0.97 (m, 3H).

5-(2-(4-((2R,3S)-2-propyl-1-(4-(trifluoromethyl)nicotinoyl)-3-((5(trifluoromethyl)thiophen-3-yl)oxy)piperidine-3-carbonyl)piperazin-1yl)phenoxy)pentanoic acid 24. LCMS m/z $=771.5(\mathrm{M}+\mathrm{H})+.{ }^{1} \mathrm{H}$ NMR $\left(400 \mathrm{MHz}, \mathrm{CDCl}_{3}\right.$ mixture of rotamers), $\delta 7.81-7.61(\mathrm{~m}, 1 \mathrm{H}), 7.20(\mathrm{~s}, 1 \mathrm{H}), 7.11(\mathrm{~s}, 1 \mathrm{H}), 7.08$ $6.98(\mathrm{~m}, 1 \mathrm{H}), 6.98-6.81(\mathrm{~m}, 4 \mathrm{H}), 6.62-6.50(\mathrm{~m}, 1 \mathrm{H}), 5.46(\mathrm{~d}, J=10 \mathrm{~Hz}$, $1 \mathrm{H}), 3.78-3.59(\mathrm{~m}, 2 \mathrm{H}), 3.46-3.31(\mathrm{~m}, 1 \mathrm{H}), 3.28-3.08(\mathrm{~m}, 4 \mathrm{H}), 3.03-2.88$ 
$(\mathrm{m}, 2 \mathrm{H}), 2.62-2.27(\mathrm{~m}, 7 \mathrm{H}), 1.64-1.35(\mathrm{~m}, 7 \mathrm{H}), 1.34-1.18(\mathrm{~m}, 3 \mathrm{H}), 1.08-$ $0.95(\mathrm{~m}, 3 \mathrm{H})$. 